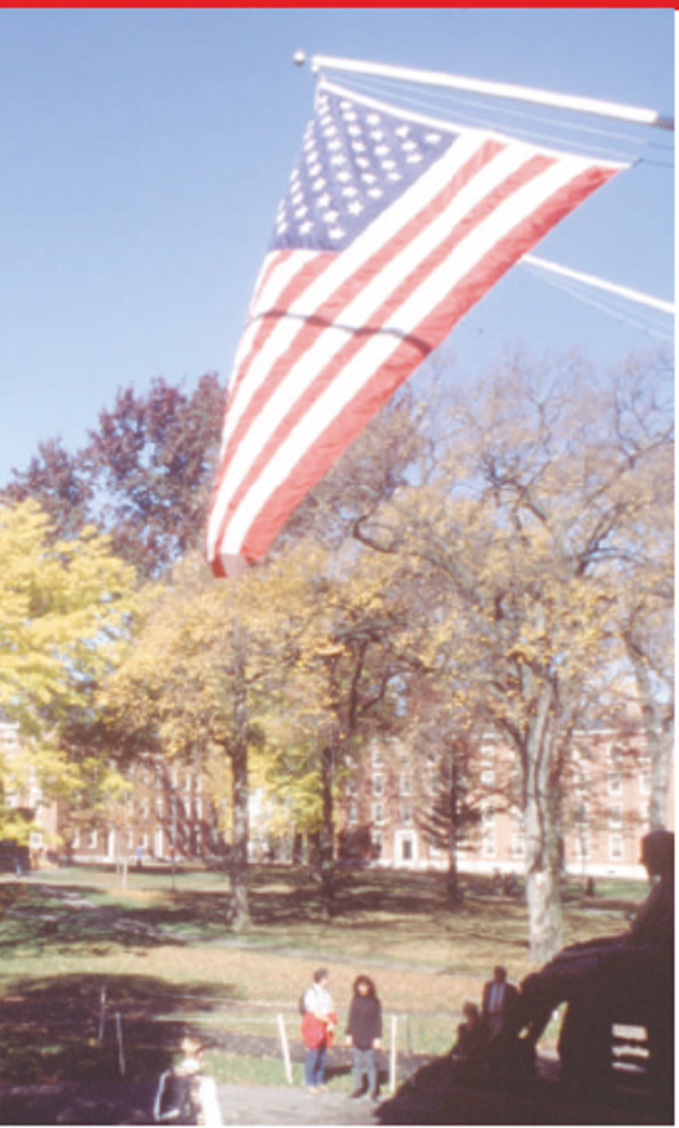

run-ins with faculty reveal the difficulties faced by a modern university leader, who must increasingly spend time away from campus raising funds and liaising with the wider community.

Although it is easy to develop sweeping plans, a good director must be able to sell them to faculty and staff, says Ingrid Moses, chancellor of the University of Canberra, Australia, and former president of the International Association of University Presidents. ${ }^{\alpha}$ They are the ones who are crucial for implementation," she says, "hence the importance of interpersonal skills." Helen Pearson

"What Europe really lacks in terms of innovation is sufficient venture capital for spin-off companies," she says. "The EIT cannot solve that problem."

Nowotny adds that althoughclusters of academicandindustrial research work well at the regional level, she doesn't believe sending industry researchersto distant university labs will boostinnovation. Barroso is confident that industry will take the bait, however. This could be crucial for the ET, as it is still unclear how the institute will be financed.

Several European companies, including Pirelli and Nokia, have welcomed the idea, buthave notspecified what they might contribute. Help may also be on the way from across the Atlantic: Microsoft founder Bill Gates has signalled that his foundation intends to support the research flagship. Quirin Schiermeier

\title{
Rules tighten for stem-cell studies
}

Researchers have taken a first stab at clarifying the conflicting rules that govern stem-cell research. A panel of more than $\mathbf{5 0}$ scientists, journal editors and ethicists have produced guidelines that they hope will promote international collaborations in a field badly shaken by the South Korean cloning scandal.

In Germany, most stem-cell research is illegal, and researchers could in theory be jailed if they participate in embryo experiments abroad. China lacks clear national policies, with different institutes following different rules. Laws also differ between US states. "The situation is likely to get worse," adds Robin Lovell-Badge, a stemcell biologist at the National Institute for Medical Research, London, and member of the panel. He says even countries with welldeveloped laws must continually update them to cope with emerging techniques.

The panel will set up a website where researchers can explain local laws and share existing ethical guidelines. It also wants journal editors to ask authors for more information relating to the ethics of the research they publish, such as the source of cells, to encourage the development of transparent ethical standards.

The group stresses the importance of obeying national laws, but calls on countries such as Germany to reconsider legislation that extends to research elsewhere. "Laws all around the world are stopping international collaboration," says panel member Julian Savulescu, an ethicist at the University of Oxford, UK.

The meeting, which took place over 22-24 February in Hinxton, UK, took two years to plan. It was not designed to tackle fraud, such as the case of Woo Suk Hwang, the South Korean scientist who faked data showing stem cells could be extracted from cloned human embryos. But the group does propose that egg donors are treated in the same way as human research subjects, meaning that Hwang's use of eggs from his researchers would probably not have been approved.

The group plans to meet again, probably within two years, to discuss new technologies such as chimaeras.

Jim Giles

For the Hinxton Group's statement

[wwwnature.com/news/2006/06022] full/440009a 